\title{
Pendampingan dalam pengembangan media pembelajaran sebagai salah satu upaya untuk memperoleh sertifikasi bagi guru-guru SMK 1 Watampone
}

\section{Dian Riani Said ${ }^{1}$, Andi Trisnowali MS2*, Andi Srimularahmah ${ }^{3}$ Aisyah Nursyam²}

${ }^{1}$ Pendidikan Bahasa Inggris, FKIP, Universitas Muhammadiyah Bone, Bone
${ }^{2}$ Pendidikan Matematika, FKIP, Universitas Muhammadiyah Bone, Bone
${ }^{3}$ Pendidikan Bahasa Indonesia, FKIP, Universitas Muhammadiyah Bone, Bone

anditrisnowali@gmail.com

\begin{abstract}
Community Service Activities in the form of assistance in the development of learning media aim to provide knowledge and skills in developing learning media that meet the requirements for certification for teachers. The ability to develop instructional media is expected to accelerate and facilitate the acquisition of in-service teacher certification. The target audience in this PPM activity is the 26 teacher of SMK 1 Watampone. Assistance in the development of instructional media is carried out by means of lectures, demonstration and exercises accompanied by question and answers. The Lecture method is used to explain the introductory concepts of professional teachers and teacher certification and the theory of instructional media. The demonstration method is used to show a work process, namely the stages of developing computer-based learning media, while the training method is to practice making media that meets the requirements of the teacher certification program. While the question and answer method is to give participants the opportunity to consult in overcoming obstacles in the development of learning media. The benefits that participants can get from activities include being able to compile and develop computer-based learning media according to the training subject being taught.
\end{abstract}

Keywords: guidance, learning media, teacher certification

\begin{abstract}
Abstrak
Kegiatan pengabdian pada masyarakat ini bertujuan untuk memberikan pengetahuan dan keterampilan dalam pengembangan media pembelajaran yang memenuhi syarat untuk memperoleh sertifikasi bagi guru. Kemampuan mengembangkan media pembelajaran diharapkan dapat mempercepat dan mempermudah perolehan sertifikasi guru dalam jabatan. Khalayak sasaran dalam kegiatan PPM ini adalah guru-guru SMK 1 Watampone yang berjumlah 26 orang. Pendampingan dilakukan dengan metode ceramah, demonstrasi dan latihan yang disertai tanya jawab. Metode ceramah digunakan untuk menjelaskan konsep pengantar guru profesional dan sertifikasi guru serta teori media pembelajaran. Metode demonstrasi dipakai untuk menunjukkan suatu proses kerja yaitu tahap-tahap pengembangan media pembelajaran berbasis komputer, sedangkan metode latihan untuk mempraktikkan pembuatan media yang memenuhi persyaratan program sertifikasi guru. Sementara metode tanyajawab untuk memberikan kesempatan para peserta berkontribusi dalam mengatasi kendala dalam pengembangan media pembelajaran. Manfaat yang dapat diperoleh peserta dari
\end{abstract}


kegiatan antara lain guru dapat menyusun dan mengembangkan media pembelajaran berbasis computer sesuai mata diklat yang diampu.

Kata Kunci: pendampingan; media pembelajaran; sertifikasi guru

\section{PENDAHULUAN}

Mutu pembelajaran merupakan sesuatu yang dinamis, relevan dengan kebutuhan masyarakat dan pengguna lulusan, berbudaya akademi kalam penyelenggaraan pembelajaran, adanya komitmen kelembagaan dari para pimpinan dan terhadap pengelolaan pembelajaran yang efektif dan produktif, memperhatikan keberlanjutan program, efisiensi serta tingginya akses terhadap perkembangan informasi. Pembelajaran yang bermutukan menghasilkan lulusan yang berkualitas pula, sedangkan untuk menghasilkan pembelajaran yang bermutu dibutuhkan guru yang profesional.

Program sertifikasi bagi guru merupakan salah satu cara yang dapat digunakan sebagai instrumen untuk memotong mata rantai penyebab rendahnya kualitas lulusan sekolah. Sertifikasi profesi guru akan dapat dilihat manakala kita sebagai guru telah layak untuk disebut sebagai guru yang profesional. Idealnya sertifikasi profesi guru dilakukan pada saat guru mulai memulai karirnya, sehingga diharapkan mereka mempunyai kompetensi profesional yang sesuai dengan perubahan dan tantangan jaman,sekaligus untuk menepis adanya anggapan bahwa rendahnya mutu pembelajaran yang berdampakpada rendahnyalulusandisebabkan oleh guru yang kurang profesional, maka pemerintah saat ini sedang menggalakkan program sertfikasi guru.

Sehubungan dengan hal itu guru-guru di Indonesia sedang berusaha untuk mendapatkan sertifikasi tersebut termasuk guru-guru di SMK 1 Watampone. Ada beberapa guru di SMK 1 Watampone yang sudah mengusulkan untuk memperoleh sertifikasi ini, namun masih banyak yang belum diterima usulannya. Salah satu komponen yang dinilai dalam program sertifikasi ini adalah pembuatan media pembelajaran dan guru-guru di SMK 1 Watampone merasa kesulitan dalam pembuatan media pembelajaran yang menarik.

Dalam menjalankan tugas sehari-hari guru akan tampil dengan sosok pribadinya dengan dunia makro dan mikronya. Hal ini merupakan hasil olahan yang amat rumit dari banyak aspek seperti cita-cita, kepercayaan moral, pengetahuan, keinginan, kemampuan, kebutuhan dan sikap (Suyanto, 2000). Selanjutnya dikatakan, kemajuan ilmu pengetahuan dan teknologi modern yang begitu pesat dan mendasar, meluas dengan cepat sangat berpengaruh pada semua aspek kehidupan seorang guru. Beranjak dari kondisi tersebut di atas maka guru harus merubah perannya sebagai sumber informasi, menjadi pencari informasi dan mengkonsumsinya secara professional. 
Sehubungan dengan hal tersebut Mulyani (1996) berpendapat bahwa peningkatan peran dan kualitas guru bisa dilakukan dengan: (1) guru tidak hanya menguasai bidang studinya, tetapi menguasai Iptek sayang memadai dan mengintegrasikannya kedalam bidang studi yang diajarkan (2) sejak dini guru perlu mananamkan nilaibudaya masyarakat induatri kepada peserta didik (3) mengintensifkan intervensi guru dalam rangka mendorong anak sadar dan mau bersekolah (4) membantu anak dalam mencari sumber informasi yang memungkinkan anak menguasai iptek (5) memberi kesempatan guru untuk studi lanjut (6) memperbaiki insentif guru (7) ada perbaikan sistes pengangkatan kepala sekolah (8) penyesuaian jenjang pendidikan dengan kebutuhan dan kemajuan iptek bagi guru dan calon guru. Diharapkan dengan upaya tersebut akan diperoleh sosok personifikasi guru yang profesional, tidak sekedar sebagai seorang pahlawan tanpa tanda jasa yang hanya bermodalkan jiwa pengabdian.

Sertifikasi bertujuan meningkatkan mutu lulusan, khususnya lulusan LPTK- PTK dan untuk memenuhi kebutuhan guru yang belum dapat disiapkan oleh LPTK- PTK. Sertifikasi membutuhkan landasan hokum yang kuat agar pelaksana program dan masyarakat pengguna jasa mempunyai kepastian hokum dan jaminan terhadap penyelenggaraan dan hasil sertifikasi. Landasan hukum tersebut mencakup:

a. Undang-undang RI Nomor: 20 tahun 2003 Tentang Pendidikan Nasional

b. Peraturan Pemerintah nomor 60 Tahun 1999 Tentang Pendidikan tinggi

c. Kepmendikbud Nomor 13/U/1998 tentang Program Pembentukan Kemampuan Mengajar

Peran sertifikasi bagi pengembangan individu:

a. Pengakuan kompetensi

Adanya kewajiban sertifikasi bagi setiap tenaga kerja berperan pada pengakuan tertulis terhadap kompetensi individu seperti yang diisyaratkan dan distandarkan, dengan demikian sertifikasi menjadi daya saing individu ketika masuk dalam dunia kerja dan juga mencegah terjadinya perlakuan-perlakuan yang diskriminatif bagi tenaga kerja tersebut.

b. Kesejahteraan

Individu karyawan yang kompeten menjalankan tugas dan tanggung jawab jabatan seperti yang dinyatakan dalam sertifikat profesinya, harus memperoleh hak yang sepadan. Dengan demikian tolok ukurnya akan menjadi jelas karena ada keseimbangan antara kompetensi dan penghargaan.

c. Membangkitkan motivasi individu

Tercapainya keseimbangan antara kompetensi dan penghargaan akan membangkitkan motivasi individu sebagai daya dorong dalam dirinya untuk terus menerus meningkatkan kompetensinya. 
Guru tidak cukup hanya memiliki pengetahuan tentang media saja, akan tetapi juga harus memiliki keterampilan memilih dan menggunakan media tersebut dengan baik. Untuk itu ia perlu mengalami latihan-latihan praktik secara kontinu dan sistematis, baik dalam re-service maupun dalam inservicetraining.

Penggunaan media didalam proses belajar mengajar tidak bermaksud menganti cara mengajar yang baik, meainkan untuk melengkapi dan membantu para guru dalam menyampaikan materi pembelajaran. Dengan mengunakan media diharapkan terjadi interaksi antara guru dengan siswa secara maksimal sehingga dapat mencapai hasil belajar yang sesuai dengan tujuan program pengabdian pada masyarakat berupa pelatihan pengembangan media pembelajaran bagi guru-guru SMK 1 Kabupaten Bone yang sudah dilaksanakan ini diharapkan dapat menambah pengetahuan, keterampilan dan lebih percaya diri dalam menjalankan profesinya. Guru akan lebih semangat dan termotivasi untuk mengembangkan diri. Hasil pelatihan ini akan bermanfaat bagi sekolah, proses belajar mengajarnya akan lebih menarik dengan digunakannya media pembelajaran yang lebih bervariasi. Disamping itu dengan adanya pelatihan pengembangan media pembelajaran ini akan menambah keterampilan guru dalam menyiapkan perangkat pembelarannya sehingga akan mendukung kemampuan guru dalam menyiapkan program sertifikasi yang mau tidak mau pasti dilakukan.

\section{METODE PELAKSANAAN}

Khalayak sasaran kegiatan pendampingan pengembangan media pembelajaran dalam rangka mempercepat perolehan sertifikasi ini adalah guru-guru SMK 1 Kabupaten Bone. Kegiatan dilaksanakan bertempat di Ruang Laboratorium Komputer SMK 1 Kabupaten Bone dengan jumlah khalayak sasaran yaitu 26 orang. Adapun yang menjadi instruktur dan narasumber dalam kegiatan ini adalah dosen-dosen STKIP Muhammadiyah Bone yang telah berpengalaman membuat media pembelajaran. Untuk memecahkan masalah yang sudah diidentifikasi dan dirumuskan tersebut di atas, agar pendampingan dapat berjalan dengan lancar maka sebagai alternatif pemecahan masalah adalah sebagai berikut: pendampingan dilakukan dengan pendekatan individual dan klasikal. Pendekatan klasikal dilakukan pada saat pemberian teori tentang pengembangan media pembelajaran yang benar dan pendekatan individual dilakukan pada saat latihan membuat media pembelajaran yang memenuhi standar sertifikasi. Adapun metode yang digunakan adalah:

1. Ceramah bervariasi.

Metode ini dipilih untuk menyampaikan konsep-konsep yang penting untuk dimengerti dan dikuasai oleh peserta pelatihan. Penggunaan metode ini dengan pertimbangan bahwa metode ceramah yang dikombinasikan dengan gambar-gambar, animasi dan display dapat memberikan materi yang relatif banyak secara padat, cepat dan mudah. Materi yang diberikan meliputi: konsep media pembelajaran, 
macam media, kelebihan dan kekurangan media, dan langkah-langkah pengembangan media pembelajaran berbasis komputer.

2. Demonstrasi

Metode ini dipilih untuk menunjukkan suatu proses kerja yaitu tahap-tahap pengembangan media pembelajaran berbasis komputer. Demonstrasi dilakukan oleh instruktur di hadapan peserta yang masing-masing mengoperasikan satu komputer sehingga peserta dapat mengamati secara langsung metode dan teknik pengembangan media pembelajaran yang layak dipakai dalam serifikasi guru.

3. Latihan

Metode ini digunakan untuk memberikan tugas kepada peserta pendampingan untuk mempraktikkan pembuatan media yang memenuhi persyaratan program sertifikasi guru.

Adapun langkah-langkah kegiatan yang dilakukan adalah pendampingan secara intensif dengan tahapan sebagai berikut:

1. Ceramah tentang pengantar guru professional dan sertifikasi guru

2. Ceramah tentang teori media pembelajaran

3. Ceramah tentang pengembangan media pembelajaran yang layak untuk sertifikasi guru

4. Demonstrasi tentang langkah-langkah penyusunan dan pengembangan media pembelajaran berbasis computer

5. Latihan pembuatan media pembelajaran

6. Evaluasi hasil media pembelajaran yang telah disusun

\section{HASIL DAN PEMBAHASAN}

Kegiatan PPM yang dilaksanakan dengan acara tata pmuka dan praktek pengembangan media pembelajaran berjalan dengan baik dan lancar. Pertemuan tatap muka dengan metode ceramah dan demonstrasi, dilanjutkan latihan/praktek untuk membuat media pembelajaran, mulai dari pemilihan materi, penyusunan, pemilihan huruf, pemberian efek dan animasi dan tampilan. Kegiatan ini dilaksanakan sehari yaitu pada hari Jumat tanggal 3 Juli 2020 dari pukul 07.30-12.00 Wita. Peserta kegiatan berjumlah 26 orang guru-guru SMK 1 Kabupaten Bone dari bidang keahlian akuntansi dan lokasi penyelenggaraan pelatihan di Ruang Laboratorium Komputer SMK 1 Kabupaten Bone.

Pelaksanan kegiatan PPM ini dilakukan oleh 3 (tiga) orang tim pengabdi dengan pokok bahasan yang disampaikan mengenai:

1. Pengantar guru professional dan sertifikasi guru

2. Teori media pembelajaran 
3. Pengembangan media pembelajaran yang layak untuk sertifikasi guru

4. Langkah-langkah penyusunan dan pengembangan media pembelajaran berbasis komputer

5. Latihanpembuatanmediapembelajaran

6. Evaluasi hasil media pembelajaran yang telah disusun.

Keterbatasan waktu pertemuan mengakibatkan tidak semua materi dapat disampaikan dengan detil. Kegiatan yang diawali dengan ceramah dan demonstrasi ini kemudian dilanjutkan latihan. Dari kegiatan latihan tampak bahwa guru memang belum menguasai cara pengembangan mediapembelajaran yang baik, khususnya media pembelajaran berbasis komputer. Acara kemudian dilanjutkan sesi tanya jawab. Berbagai pertanyaan diajukan secara antusias oleh para peserta dalam sesi tanya jawab. Secara garis besar inti dari pertanyaan para peserta adalah:

1. Syarat-syarat penyusunan media pembelajaran yang baik

2. Langkah-langkah pembuatan media pembelajaran berbasis komputer dengan cepat.

3. Penggantian layout, font dan background dalam penyusunan media pembelajaran berbasis komputer.

4. Pembuatan table dalam slide.

5. Pemberian efek suara dan animasi dalam penyusunan mediapembelajaran berbasis komputer.

6. Pengaturan tampilan media pembelajaran berbasis komputer bagi audiens

\subsection{Pembahasan Hasil Pelaksanaan Kegiatan}

Hasil kegiatan PPM secara garis besar mencakup beberapa komponen sebagai berikut:

1. Keberhasilan target jumlah peserta pelatihan

2. Ketercapaian tujuan pelatihan

3. Ketercapaian target materi yang telah direncanakan

4. Kemampuan peserta dalam penguasaan materi

Target peserta pelatihan seperti direncanakan sebelumnya adalah paling tidak 25 guru di SMK 1 Kabupaten Bone, sesuai dengan jumlah computer yang tersedia di laboratorium. Dalam pelaksanaannya, kegiatan ini diikuti oleh 26 orang peserta. Dengan demikian dapat dikatakan bahwa target peserta tercapai $100 \%$. Angka tersebut menunjukkan bahwa kegiatan PPM dilihat dari jumlah peserta yang mengikuti dapat dikatakan berhasil/sukses.

Ketercapaian tujuan pendampingan pengembangan media pembelajaran secara umum sedah baik, namun keterbatasan waktu yang disediakan mengakibatkan tidak semua materi tentang pengembangan media pembelajaran dapat disampaikan secara detil. Namun dilihat dari hasil latihan para peserta yaitu kualitas media pembelajaran 
yang telah dihasilkan, maka dapat disimpulkan bahwa tujuan kegiatan ini dapat tercapai.

Ketercapaian target materi pada kegiatan PPM ini cukup baik,karena materi pendampingan telah dapat disampaikan secara keseluruhan. Materi pendampingan yang telah disampaikan adalah:

1. Pengantar guru professional dan sertifikasi guru

2. Teorimediapembelajaran

3. Pengembangan media pembelajaran berbasis komputer

Kemampuan peserta dilihat dari penguasaan materi masih kurang dikarenakan waktu yang singkat dalam penyampaian materi dan kemampuan para peserta yang berbedabeda. Hal ini disebabkan jumlah materi yang banyak hanya disampaikan dalam waktu sehari sehingga tidak cukup waktu bagi para peserta untuk memahami dan mempraktekkan secaralengkap semua materiyang diberikan.

Secara keseluruhan kegiatan pendampingan pengembangan media pembelajaran untuk mempercepat guru memperoleh sertifikasi ini dapat dikatakan berhasil. Keberhasilan ini selain diukur dari keempat komponen diatas juga dapat dilihat dari kepuasan peserta setelah mengikuti kegiatan. Manfaat yang diperoleh guru adalah dapat menyusun dan mengembangkan media pembelajaran dengan kualitas yang lebih baik dan diharapkan kualitas tersebut sudah mengikuti standar untuk dapat dipakai sebagai poin dalam penilaian portofolio sertifikasi guru.

\section{SIMPULAN}

Program pendampingan dapat diselenggarakan dengan baik dan berjalan dengan lancar sesuai dengan rencana kegiatan yang telah disusun meskipun belum semua peserta pendampingan menguasai dengan baik materi yang disampaikan. Kegiatan ini mendapat sambutan sangat baik terbukti dengan keaktifan peserta mengikuti pendampingan dengan tidak meninggalkan tempat sebelum waktu pelatihan berakhir.

\section{REFERENSI}

(1993). Kerangka Acuan Pemasyarakatan Kebijakan Pendidikan dan Kebudayaan.Jakarta.

Kepmendikbud Nomor 13/U/1998 tentang Program Pembentukan Kemampuan Mengajar Peraturan Pemerintah nomor 60 Tahun. Tentang Pendidikan tinggi

MulyaniA.N.(1996). Peranan Fakultas Keguruan Dan Fakultas Ilmu Pendidikan Bagi Peningkatan Kualitas Profesional Guru Tenaga Kependidikan Lainnya. Makalah seminar temu alumni IKIP Yogyakarta. (1996). Yogyakarta: IKIP Yogyakarta 
Suyanto (2003). Sertfikasi Profesi Guru:Jaminan Pengakuan Sekaligus Ancaman. Seminar Nasional "Merekonstruksi Profesi Guru Memasuki Era Global dan Otonomi"Semarang:UNESA

Undang-undang RI Nomor: 20 tahun 2003 Tentang Pendidikan Nasional 